\title{
Small-scale Structure of Infaunal Polychaete Communities in an Estuarine Environment: Methodological Approach
}

\author{
D. Martin ${ }^{1}$, E. Ballesteros ${ }^{1}$, J. M. Gili ${ }^{2}$ and C. Palacín ${ }^{2}$ \\ ${ }^{1}$ Centre d'Estudis Avançats de Blanes (CSIC) Camí de Santa Bàrbara, s/n, 17300- \\ Blanes ( Girona), Spain and Institut de Ciències del Mar (CSIC), \\ Passeig Nacional s/n, 08003-Barcelona, Spain
}

Keywords: community structure; small-scale; sampling-area; shallow-water;

Polychaeta; NW Mediterranean

This study compares different methods for the estimation of minimal areas (viz. species/area curves, diversity/area curves, similarity/area curves, variance/mean ratio vs. area curves) as community structure descriptors. The comparisons are based upon two polychaete taxocoenoses from muddy and sandy habitats, located in a semienclosed shallow-water Mediterranean bay (Alfacs Bay, Ebro Delta, NW Mediterranean).

The mud community appeared to be very homogeneous, with very low diversity. This community displayed high structural Simplicity (related to various stress factors), and therefore, qualifies as a physically controlled community). The diversity index was stabilized for areas of $37 \mathrm{~cm}^{2}$, quantitative similarity (Kulczynski index) was higher than 0.7 for areas of $90 \mathrm{~cm}^{2}$ and density of individuals was stabilized for areas of 120 $\mathrm{cm}^{2}$. Therefore, an area of $120 \mathrm{~cm}^{2}$ is suggested as being representative of the community structure. However, it was impossible to define a qualitatively adequate sampling area $\left(>300 \mathrm{~cm}^{2}\right)$.

The sand community displayed high structural complexity, with high species richness and high diversity. This community was characterized by high environmental stability and high variability of microhabitats, as is frequent in biologically accommodated communities. The number of individuals became homogeneous for areas of $600-1000 \mathrm{~cm}^{2}$, diversity was stabilized around $300 \mathrm{~cm}^{2}$ and a Kulczynski similarity index of 0.7 was already attained at areas of $1000 \mathrm{~cm}^{2}$. Thus, a quantitatively representative sampling area of between 700 and $1000 \mathrm{~cm}^{2}$ was suggested. Moreover, the more general pattern of species distribution (with an important set of common species) was directly related to the relatively low qualitative minimal area $\left(400 \mathrm{~cm}^{2}\right)$. 


\section{Introduction}

The description of patterns in the distribution and abundance of organisms is an essential goal in ecology. Observed patterns are the basis on which models are built, and hypotheses formed and tested by experiments. Thus, observed patterns usually provide the context within which the results of experiments are interpreted.

In turn, suitable descriptions are strictly dependent on adequate methodology. Therefore, samples must represent qualitatively and quantitatively the community or communities to be studied. At the same time, sampling effort must also be cost-effective with regard to the information obtained (Ballesteros, 1986).

The balance between representativeness and cost-effectiveness constitutes the axis around which the philosophy of minimal areas rotates, particularly in certain studies on marine benthic ecology. The finding of a minimal area (to justify sampling adequacy) should always be a primary step in the planning of any community study. Unfortunately, these kinds of studies are seldom carried out and, if so, tend to be inaccessible. On the contrary, studies proceeding by standardized sampling methods (even intuitive methods) are habitually and quite uncritically accepted. Adequacy of sampling methods is seldom demonstrated, with custom or tradition guiding the planning, instead of previously evaluating the possibilities of adequate sampling designs (Andrew \& Mapstone, 1987). However, one must point out that the different minimal area methods (viz. species/area curves, qualitative similarity/area curves, variance-mean ratio vs. area curves, diversity/area curves, qualitative similarity/area curves) provide, at the same time, excellent descriptors of community structure.

Estimates of an adequate sampling area are of less importance when one considers the additional information generated by the minimal area methods (Ballesteros, 1986). Although the value of these methods has been demonstrated in phytobenthic studies (Boudouresque, 1971; Boudouresque \& Luck, 1972; Nie11, 1977; Ballesteros, 1984), they have seldom been used in the study of animal communities (Weinberg, 1978; Hawkins \& Hartnoll, 1980; Laborda, 1984; Gili \& Ros, 1985; Kronberg, 1987; Gili \& Ballesteros, 1991). Moreover their application to soft-bottom communities has been virtually nil.

The present study focuses on a comparison between the different minimal area methods when applied to the taxocoenosis of Polychaeta inhabiting a semi-enclosed 
shallow-water Mediterranean bay (Palacín et al., 1991). In particular, this study investigates (a) the structure of the polychaeta taxocoenosis, (b) the usefulness of the information furnished by the different minimal methods in interpreting community structure and, (c) the relationships between community structure and environment.

\section{Material and methods}

\section{Study area}

Alfacs Bay (Ebro Delta), located on the North-East coast of the Iberian Peninsula (NorthWestern Mediterranean, 40³3'-38'N, 0³2'-44'E) (Figure 1), is a semi-enclosed shallow-water area, which can be characterized as a ' paralic' environment (sensu Geulorguet \& Pertuisot, 1983). Muddy and sandy regions have been previously identified in the inner part of the Bay (Figure 1, Table 1) (Palacín et al., 1991).

The sediment of the muddy region was very compact, with high organic matter, silt and clay contents, and a strongly negative Redox potential (Table 1). There were scattered shoots of the marine seagrasses Ruppia cirrhosa (Petagna) Grande and Cymodocea nodosa (Ucria) Ascherson in the area (Pérez \& Camp, 1986). Moreover, large aggregates of floating sheet-like algae (mainly Ulva spp.) were occasionally accumulated on the shore, depending on the dominant currents (Martinez, 1990). The water column, though variable in height, was deep enough to keep the sediment submerged at all times (Table 1).

The sandy region showed coarse sediments, with very low organic matter, silt and clay contents, together with a rather high Redox potential (Table 1). Shoots of $C$. nodosa were distributed in patches, denser than in the muddy region (Pérez, 1989; Duarte \& Sand-Jensen, 1990). Changes in the water column depth were more noticeable than in the muddy region but, again, the sediment was never exposed (Table 1).

\section{Sampling methods}

A series of ten samples were collected at random from each region under study by means of manual cores.

Based upon previous studies on the polychaete fauna of both communities (Martin, 1991; Palacín et al., 1991), sample size was $30 \mathrm{~cm}^{2}$ in the muddy region and $200 \mathrm{~cm}^{2}$ in 
the sandy region.

Each sample was filtered and fauna collected on a $500 \mu \mathrm{m}$ sieve. Afterwards, all the polychaete species were separated, identified and quantified using a stereo microscope (Wild Heerbrug M-8). The collected specimens were preserved in buffered $10 \%$ seawater formalin.

Qualitative and quantitative data were used to plot all the descriptors /area curves. Mean values of each descriptor for successively larger areas were calculated considering all the possible combinations of samples and plotted vs. their respective areas to obtain the curves.

To obtain the similarity/area curves, non-repeating combinations of samples had to be used in order to not artificially increase the similarity.

\section{Studied parameters}

\section{Dominance and frequency}

Dominance index (D) was calculated as follows;

$$
\mathrm{D}=n \times 100 / \mathrm{N}
$$

where ' $n$ ' is the total number of individuals of a given species and ' $N$ ' is the total number of individuals (Soyer, ]970).

Frequency index (F) was calculated as:

$$
\mathrm{F}=m \times 100 / \mathrm{M}
$$

where ' $m$ ' is the number of samples in which a given species was recorded and ' $\mathrm{M}$ ' is the total number of samples (Soyer, 1970).

Species were considered rare species when they had a low dominance $(\mathrm{D}<1 \%)$ and a low frequency $(\mathrm{F} \leq 50 \%)($ Soyer, 1970).

\section{Species/area curves}

The observed species/area curves were fitted to a semi logarithmic function (Gleason, 1925):

$$
\mathrm{y}=a \mathrm{x} \ln \mathrm{x}+b
$$

where ' $\mathrm{x}$ ' is the area in $\mathrm{cm}^{2}$ and ' $\mathrm{y}$ ', is the species number. The adjusted function can be expressed as a potential curve: 


$$
\mathrm{x}=k \mathrm{x} \mathrm{e}^{\mathrm{iy}}
$$

with ' $\mathrm{k}$ ' $=\mathrm{e}^{-\mathrm{b} / \mathrm{a}}$ and ' $\lambda$ ' $=1 / \mathrm{a}$.

Estimates of the Molinier points have been frequently used to determine qualitative minimal areas (Boudouresque \& Belsher, 1979; Ballesteros, 1984, 1986). A Molinier point $(\mathrm{M} \mathrm{x} / \mathrm{y})$ corresponds to a point from the species/area curve in which an $\mathrm{x} \%$ of area increase is related to a $\mathrm{y} \%$ increase in species number. These points can be found solving the equations

$$
\begin{aligned}
& x=\mathrm{kx} \mathrm{e}^{\lambda y} \\
& \mathrm{x}+\mathrm{dx}=\mathrm{kx} \mathrm{e}^{\lambda\left(\mathrm{y}+\mathrm{d}^{\prime} \mathrm{y}\right)}
\end{aligned}
$$

where $d x$ and d'y are, respectively, the relative increments of surface and species number (expressed as percentages). The solution can be expressed as:

$$
\mathrm{x}=k \mathrm{xe}^{\left.\left[\ln (1+\mathrm{dx}) / \mathrm{d}^{\prime} \mathrm{y}\right)\right]}
$$

Therefore, the Molinier point $(\mathrm{x} / \mathrm{y})$ depends on the relative increments of surface $(\mathrm{dx})$ and species number (d'y) chosen, the $k$ value being characteristic of each curve. Moreover, $k$ is considered to be a good descriptor of the curve shape, providing useful information about the qualitative distribution of species inside the community (Ballesteros, 1986). A Molinier point M 20/4 (=95.4k) (Ballesteros, 1986), has been chosen as representative in the present study.

\section{Qualitative similarity/area curves}

The Sorensen index (Sorensen, 1948) has been used to calculate qualitative similarity/area curves. The $\mathrm{I}_{\mathrm{s}}$ index has been calculated as:

$$
\mathrm{I}_{\mathrm{s}}=2 \mathrm{C}_{\mathrm{pq}} /\left(\mathrm{n}_{\mathrm{p}}+\mathrm{n}_{\mathrm{q}}\right)
$$

where $e_{\mathrm{pq}}$ is the number of species common to the samples $\mathrm{p}$ and $\mathrm{q}$, and $\mathrm{n}_{\mathrm{p}}$ and $\mathrm{n}_{\mathrm{q}}$ are, respectively, the total number of species in the samples $p$ and $q$. The value of $I$ ranges from 0 (total dissimilarity) to 1 (total similarity or identity). For the definition of a qualitative minimal area, a similarity index of 0.85 is deemed satisfactory (Weinberg, 1978).

Variance/mean ratio of the number of individuals vs. area

Changes in the variance/mean ratio (estimated on the basis of abundance values) vs. area are related to the aggregation level of individuals and, consequently, information about density patchiness can be directly inferred (Ballesteros, 1986). Maximum values 
in the curve indicate areas in which density differences are higher, while absolute values of the quotient point out the magnitude of the aggregation level.

\section{Diversity/area curves}

The Shannon index (Shannon, 1948), widely used as a diversity index, can be expressed as:

$$
\mathrm{H}^{\prime}=-\sum_{\mathrm{i}=1}^{\mathrm{n}} \mathrm{pi} \lg _{2} \mathrm{p}_{\mathrm{i}}
$$

where $H^{\prime}$ is the diversity of the sample, $p_{i}$ the proportion of individuals found in the ith species, and $n$ the species number.

The Shannon index/area curves can be fitted by least squares to a MichaelisMenten function:

$$
\mathrm{y}=\mathrm{Ax} /(\mathrm{B}+\mathrm{x})
$$

after transformation to:

$$
1 / \mathrm{y}=\mathrm{B} / \mathrm{A} \times 1 / \mathrm{x}+1 / \mathrm{A}
$$

If the sampling area is increased to infinity, then

$$
\lim _{x \rightarrow \infty}[A x /(B+x)]=A
$$

so, the A values are good estimates of the community's global diversity, referred to as alpha-diversity or species diversity (Ballesteros, 1986).

Values of the slope, for each area size, characterize each curve. Niell (1974) assumed that stabilization of diversity /area curves is attained when the slope is not significantly distinct from zero. In the case of the fitted diversity/area curves, the value of area $\mathrm{x}$ corresponding to a $\mathrm{z}$ slope can be calculated by deriving the Michaelis-Menten function:

$$
y^{\prime}=A B / B^{2}+2 B x+x^{2}
$$

Naming $y$, as $z$, the surface at which the curve will have a $z$ slope is:

$$
\mathrm{x}=-\mathrm{B}+\sqrt{\mathrm{AB} / \mathrm{z}}
$$

Diversity stabilization can be assumed when the slope reaches a value of $1 \times 10^{-3}$ (Ballesteros, 1986). In which case, the $\mathrm{x}$ value of area can be regarded as a structural minimal area (Ballesteros, 1986, 1991), as well as providing a good estimate of the pattern diversity. 
The Kulczynsky index (Kulczynsky, 1927) has been chosen to calculate quantitative similarity/area curves. The $\mathrm{I}_{\mathrm{k}}$ index has been calculated according to:

$$
\mathrm{I}_{\mathrm{k}}=\frac{2 \sum_{\mathrm{i}=1}^{\mathrm{n}} \inf \left(\mathrm{R}_{\mathrm{ip}}, \mathrm{R}_{\mathrm{iq}}\right)}{\sum_{\mathrm{i}=1}^{\mathrm{n}}\left(\mathrm{R}_{\mathrm{ip}}+\mathrm{R}_{\mathrm{iq}}\right)}
$$

where $R_{i p}$ and $R_{i q}$ are the number of individuals per surface unit of species $i$ respectively in samples $p$ and $q$, and $\inf \left(\mathrm{R}_{\mathrm{ip}}, \mathrm{R}_{\mathrm{iq}}\right)$ is the value of $\mathrm{R}_{\mathrm{ip}}$ or $\mathrm{R}_{\mathrm{iq}}$ whichever is smaller. The value of $I_{k}$ ranges from 0 (total dissimilarity) to 1 (total similarity or identity). In that case, a similarity of 0.7 seems to be satisfactory for the definition of a quantitative minimal area (Weinberg, 1978; Ballesteros, 1986).

\section{Results}

The species (together with their respective abundances) of the 10 samples from both muddy and sandy stations are summarized in Table 2.

The muddy polychaete taxocoenosis was characterized by a low number of species. Moreover, rare species were relatively more important qualitatively $(71.4 \%$ of the total species number) than quantitatively (1.1\% of the total number of individuals). On the other hand, the sandy taxocoenosis showed higher species number, with a proportionally low frequency of rare species (29.4\% of the total) showing a higher number of individuals ( $3 \%$ of the total number of individuals).

\section{Species/area curves}

Species/area curves showed different trends in mud and sand communities [Figure 2(a)]. Curves were fitted as:

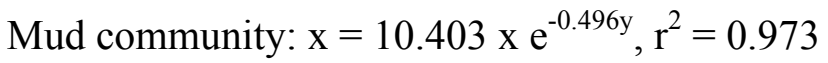

Sand community: $\mathrm{x}=1.0053 \mathrm{x} \mathrm{e}^{-0.438 \mathrm{y}}, \mathrm{r}^{2}=0.961$

The Molinier point M 20/4 was attained at areas of $992.5 \mathrm{~cm}^{2}$ (muddy) and $95.9 \mathrm{~cm}^{2}$ (sandy), respectively. Thus, both communities were clearly distinguishable: while the 
sandy minimal area would be lower than $100 \mathrm{~cm}^{2}$ (the size of one sample), the muddy minimal area would be higher than the surface represented by all the collected samples. Moreover, estimates of $\mathrm{k}$ were higher in the mud community (FI) than in the sand community (F2), highlighting a more scattered qualitative species distribution in the former.

\section{Qualitative similarity ( Sorensen index) / area}

Qualitative similarity was always lower in the mud community than in the sand community [Figure 2(b)]. A similarity value of 0.85 was already exceeded when combining two samples in the sand community $\left(400 \mathrm{~cm}^{2}\right)$, while it was never reached in the mud community $\left(>150 \mathrm{~cm}^{2}\right)$.

\section{Variations of the variance/mean ratio of the number of individuals vs. area}

No significant peaks were observed in the curve of variance/mean ratio vs. area, suggesting that there were no intermediate patch sizes inside the communities.

Dispersion of individuals (expressed by the variance/mean quotient) becomes very low at areas of $120 \mathrm{~cm}^{2}$ (mud) and of $600-1000 \mathrm{~cm}^{2}$ (sand), respectively [Figure 3 (a)]. Density of individuals can be considered to remain constant for larger areas.

\section{Diversity/area curves}

Differences between the two studied polychaete populations were also evident in the Shannon diversity index. The high dominance of S. shrubsoli caused low diversity values (hardly 0.2 bits for an area of 10 samples) in the mud community, whilst the sand community reached a rather higher value ( $3 \cdot 2$ bits also for 10 samples) [Figure 3(b)].

The fitted Michaelis-Menten curves obtained for the muddy and sandy communities were:

$$
\begin{aligned}
& \text { Mud community: } \mathrm{y}=0.211 \mathrm{x} /(10.764+\mathrm{x}), r^{2}=0.813 \\
& \text { Sand community: } \mathrm{y}=3.299 \mathrm{x} /(23.816+\mathrm{x}), r^{2}=0.972
\end{aligned}
$$

The alpha-diversity values, 0.211 (F3) and 3.299 (F4), characterized, respectively, the different complexities of mud and sand communities.

Slope values of $1 \times 10^{-3}$ were reached for areas of $37 \mathrm{~cm}^{2}$ (mud) and of $256 \mathrm{~cm}^{2}$ (sand), respectively (both sizes exceeded when combining more than 1 sample). Thus, the two taxocoenoses studied were structurally quite well represented by the above mentioned area sizes. 
Quantitative similarity (Kulczynski index) vs. area

Muddy samples proved to be very uniform [Figure 3(c)], with a 0.70 value of the Kulczynski index being exceeded when the sampling area reached $90 \mathrm{~cm}^{2}$. On the other hand, in the sand community, this value was scarcely attained for a sampling area of $1000 \mathrm{~cm}^{2}$.

\section{Discussion}

The dominant species in the mud community were small-sized opportunistic depositfeeders (Grassle \& Grassle, 1979) (Table 2). They usually display high turnover ratios and their reproductive periods extend practically all year round (Martin, 1991). Their burrowing ability is poor or non-existent. In consequence, these species usually have low bioturbation power (at least vertically in the sediment), but they have the ability to process the resources available in the first few millimeters of sediment. The spionid $S$. shrubsoli, a surface deposit-feeder (Gambi \& Giangrande, 1985), shows the highest dominance values, but the dominance of $C$. capitata, a subsurface deposit-feeder (Gambi \& Giangrande, 1985), was also of importance.

Species of the mud community were scattered in such a way that the species number did not become stable for the considered area ranges, and new species probably would still appear for larger areas. This was clearly reflected by the species/area curve, unstabilized for areas of $300 \mathrm{~cm}^{2}$ [Figure 2(a)], but also by the high values of $\mathrm{k}$ and the Molinier point M 20/4 (F1) and by the low Sorensen index values [Figure 2(b)].

Quantitatively, the mud community showed strong small-scale differences in density (for areas lower than $90 \mathrm{~cm}^{2}$ ) [Figure 3(a)], demonstrating a pronounced patchiness of distribution of individuals at this level. Nevertheless, density differences quickly decreased as surface area increased. Moreover, the high dominance of a single species, S. shrubsoli, caused low species diversity values, together with practically no increase in the diversity index related to the sampling area increments (low pattern diversity) [Figure 3(b)]. This structural simplicity was also reflected by the quantitative homogeneity, the Kulczynski index value of 0.7 being reached at sampling areas of 90 $\mathrm{cm}^{2}$ [Figure 3(c)].

In short, the mud community appeared as a very homogeneous community, with 
extraordinarily low diversity. Diversity stabilization for areas of $37 \mathrm{~cm}^{2}$, quantitative homogeneity higher than 0.7 for areas of $90 \mathrm{~cm}^{2}$, and density stabilization for areas of $120 \mathrm{~cm}^{2}$, suggest an area of $120 \mathrm{~cm}^{2}$ (four samples) as being representative of the community structure. However, new species would still appear for successively larger areas $\left(>300 \mathrm{~cm}^{2}\right)$, as it was impossible to define a qualitatively adequate sampling area.

Structural simplicity of the mud community may be related to one or various stress factors, limiting diversification possibilities: hypoxia practically at a zero level, dense compactness of sediment, high organic matter contents, etc. (Pearson \& Rosenberg, 1978). Thus, the mud community may be considered a physically-controlled community (sensu Sanders, 1969), where more resistant species (e.g. S. shrubsoli) are favored, occupying all the space available. Environmental spatial homogeneity may also be a contributing factor in maintaining low levels of species heterogeneity. The relatively high number of rare species (always represented by a few individuals) could be directly related to chance. The absence of complex competence networks in physically-controlled communities may allow the presence of transient species which would not necessarily be well adapted to the particular environmental conditions.

The sandy polychaete taxocoenosis is characterized by the presence of species with a wide range of sizes and trophic strategies (Table 2). Most of the species reproduce annually and often have a lifespan of over a year. These species are able to burrow (and to modify) deep into the sediment, the majority being large subsurface deposit-feeders, such as the capitellids Notomastus latericius and Mastobranchus trinchesi.

The sand community was richer in species than the mud community. Moreover, its species distribution pattern became more general, with a group of common species and few rare species [Figure 2(a)]. This high small-scale species richness was directly related to the low k and M 20/4 values (F2) and to the high qualitative homogeneity reached for low area sizes [Figure 2(b)].

The spatial pattern of the sand community was clearly defined by the evolution of the different quantitative parameters $v s$. area: the number of individuals becoming homogeneous for areas of 600-1000 $\mathrm{cm}^{2}$, diversity stabilizing around $300 \mathrm{~cm}^{2}$ and Kulczinsky similarity index of 0.7 already attained at areas of $1000 \mathrm{~cm}^{2}$. Thus, the structural pattern of the sand community was quite different from the mud one, with a number of species of equal dominance and a representative sampling area being between $700-1000 \mathrm{~cm}^{2}$ (four to five samples). 
The highest structural complexity of the sandy polychaete taxocoenosis may be directly related to the higher environmental stability and to the higher diversity of microhabitats (coarse sand, deeper oxygenated sediments, enough available food, etc.). Because of this, resources had to be widely distributed, especially through the sediment column, thus leading to the existence of a high number of species. In this way, a high specific coexistence together with an intense, but well distributed, interaction between species competing for the same food resource should be maintained. Therefore, the sandy community may be considered a biologically accommodated community, sensu Sanders (1969).

Species diversity decreases when organisms are exposed to severe physical stress (physically-controlled communities), as in the muddy polychaete taxocoenosis. Nevertheless, that is not the sole effect. In fact, each measured structural parameter seems to be affected by stress, resulting in a reduced number of species, a low pattern diversity, and high homogeneity. On the contrary, whether environmental factors are more suitable for maintaining several species and the architecture of the habitat permits the coexistence of different microhabitats -as in the sandy polychaete taxocoenosisboth species diversity and pattern diversity increase and there is higher heterogeneity and species number.

The different minimal area methods that have been used in the present study have all provided valuable information depending on their qualitative or quantitative character and on their species-discriminant capability. A detailed interpretation of the curves of the proposed descriptors $v s$. areas, together with the parameters inferred from the curves, have provided clear community descriptions. Moreover, reasonable estimates of minimal areas have been proposed to facilitate the design of future seasonality or population dynamics studies.

Our study provides two different levels of interpretation using the curves of the different indexes $v s$. area: the sampling-design-methodology level and the communitystructure descriptor level. We propose that a minimum of two methods, one quantitative and the other qualitative, should be used when dealing with the former level. On the other hand, we recommend the use of several qualitative and quantitative methods when interested in the latter level, taking into account that, in this way, non redundant, complimentary information can be inferred.

The sandy and muddy polychete taxocoenosis studied in the shallow-water bay of the Ebro Delta greatly differ in their structure. Environmental factors and architectural 
features of the sediment seemed to be the main contributors to community patch-size, which increases in more stable communities (e.g. the sand community) and decreases in communities affected by environmental stress (e.g. the mud community). Our results provide new evidence supporting the theory that stress may be an important cause of structural simplification in natural communities.

\section{References}

Andrew, N. L. \& Mapstrone, S. D. 1987 Sampling and the description of spatial pattern in marine ecology. Oceanography and Marine Biology an Annual Review 25, 39-90.

Ballesteros, E. 1984 Els vegetals $i$ la zonacio litaral: especies, comunitats $i$ factors que infiueixen en la seva dislribució. Ph.D. thesis, Universitat de Barcelona.

Ballesteros. E. 1986 Métodos de anélisis estructural en comunidades naturales, en particular de1 fitobentos. Oecologia Aquatica 8, 117-131,

Ballesteros, E. 1991 Structure and dynamics of North·Western Mediterranean marine communities: a conceptual model Oecologia Aqualica 10, 223-242.

Boudouresque, C. F. 1971 Méthodes d'étude qualitative et quantitative du benthos (en particulier du phytobenthos). Téthys 1, 83-184.

Boudouresque, J. C. F. \& Belsher, T. 1979 Le peuplement algal du port de Port-Vendres: recherches sur l'aire minimal Qualitative. Cahiers de Biologie Marine 20, 259-268.

Boudouresque, C. F. \& Luck, H . B. 1972 Recherches de bionomie structurale au niveau d'un peuplement benthique sciaphile. Journal of Experimemal Marine Biology and Ecology 8, 133-144.

Duarte, C. M. \& Sand-J ensen, K. 1990 Seagrass colonization: patch function and patch growth in Cymodocea noosa. Marine Ecology Progress Series 65, 193-200.

Fauchald, K. \& Jumars, P. A. 1979 The diet of worms: A study of Polychaete feeding guilds. Oceanography and Marine Biology an Anrtual Review 17, 193-284.

Gambi, M. C. \& Giangrande, A. 1985 Caratterizzazione e distribuzione delle categorie trofiche dei Policheti nei fondi mobili del golfo di Salerno. Oebalia 11, 22 240.

Gili, J. M. \& Ballesteros, E. 1991 Structure of Cnidarian populations in Mediterranean sublittoral benthic communities. Oecologia Aquatica 10, 243-254.

Gili, J. M. \& Ros, J. D. 1985 Estudio cuantitativo de tres poblaciones circalitorales de Cnidarios bentónicos. Investigación Pesquera 49, 323-352.

Gleason, H. A. 1925 Species and area. Ecology 6, 66-74.

Grassle, J. F. \& Grassle, L. S. 1974 Opportunistic life histories and genetic systems in marine benthic polychaetes. Journal of Marine Research 32, 253-284.

Guelorget, O. \& Perthuissot, J. P. 1983 Le domaine paralique: Expressions géologiques, biologiques et économiques du confinement. Travaux du Laboratoire de Géologie, Ecole Normale Supérieure, Paris $16,1-136$.

Hawkins, S. J. \& Hartnoll, R. G. 1980 A study of the small-scale relationships between species number 
and area on a rocky shore. Estuarine and Coostal Marine Science 10,201-214.

Kronberg, I. 1987 Accuracy of species and abundance minimal areas determined by similarity area curves. Marine Biology 96, 555-561.

Kulczynski, S. 1927 Die Pftanzenassoziationen der Pieninen. Bulletin International Acadèmie Tchèque des Sciences 3, 57-203.

Laborda, A. J. 1984 Estudio de la macrofauna bentónica sobre sustrrato blando del piso intermareal de la playa de covas (o de El Grallal), Ria de Vivero, Lugo. Ph.D. thesis, Universidad de León.

Martin, D. 1991 Macroinfauna de una bahia Mediterránea. Estudio de los niveles de organización de las pcblaclones de Anélidos Poliquetos. Ph.D. thesis, Universitat de Barcelona.

Martínez, M. A. 1990 Estudio ecológico de las algas Efemerofíceas: Papel en los fiujos de materia y energia en un sistema estuárico (Bahia de los Alfaques, Delta del Ebro). Ph.D. thesis, Universitat de Barcelona.

Niell, F. X. 1974 Les applications de l'index de Shannon a l'étude de la végétation intertidale. Bulletin de la Société Phycologique de France 19, 238-254.

Niell, F. X. 1977 Método de recolección y área mínima de muestreo en estudios estructurales del macrofitobentos rocoso intermareal de la ría de Vigo. Invescigaciones Pesqueras 41, 506-521.

Palacín, c., Martin, D. \& Gili, J. M. 1991 Features of benthic in fauna in a Mediterranean shallow-water bay. Marine Biology 106, 101-107.

Pearson, T. H. \& Rosenberg, R. 1978 Macrobenthic succession in relation to organic enrichment and pollution in marine environment. Oceanography and Marine Biology an Annual Review 16, 229- 311.

Pérez, M. \& Camp, J. 1986 Distribución espacial y biomasa de las fanerógamas marinas de las bahías del Delta del Ebro. Investigaciones Pesqueras 50, 519- 530.

Sanders, H. L. 1969 Benthic marine diversity and the stability-time hypothesis. Brookhaven Symposium Biology 22, 71-80.

Shannon, C. E. 1948 A mathematical theory of communication. Belgium Systems and technics fournishing 27, 379-423, 623-656.

Sorensen, T. 1948 A method of stablishing groups of equal amplitude in plant sociology based on similar species content and its application to analyses of vegetation on Danish commons. Biologiske Skrifter 5, $1-34$.

Soyer, J. 1970 Bionomie benthique du plateau continental de la cote catalane française. III. Les peuplements de Copépodes harpacticoides (Crustacea). Vie et Milieu 21, 337- 511.

Weinberg, S. 1978 The minimal area problem in invertebrate communities of Mediterranean rocky substrata. Marine Biology 49, 33-40. 
Figure 1. Location of sampling stations

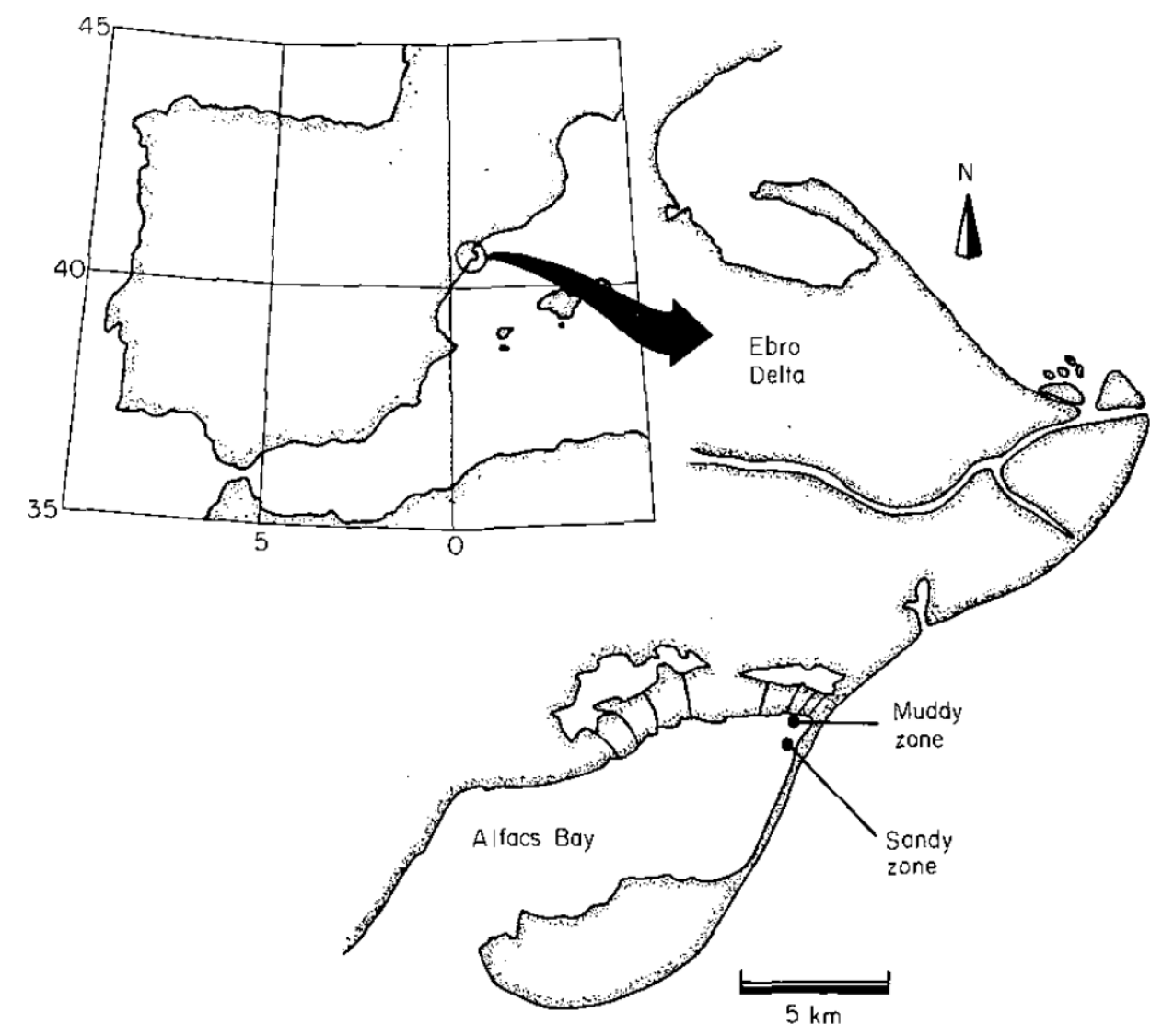


Figure 2.- (a) Species/area curves. (b) Sorensen index/area curves. ——- Silty; -

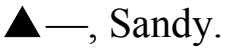
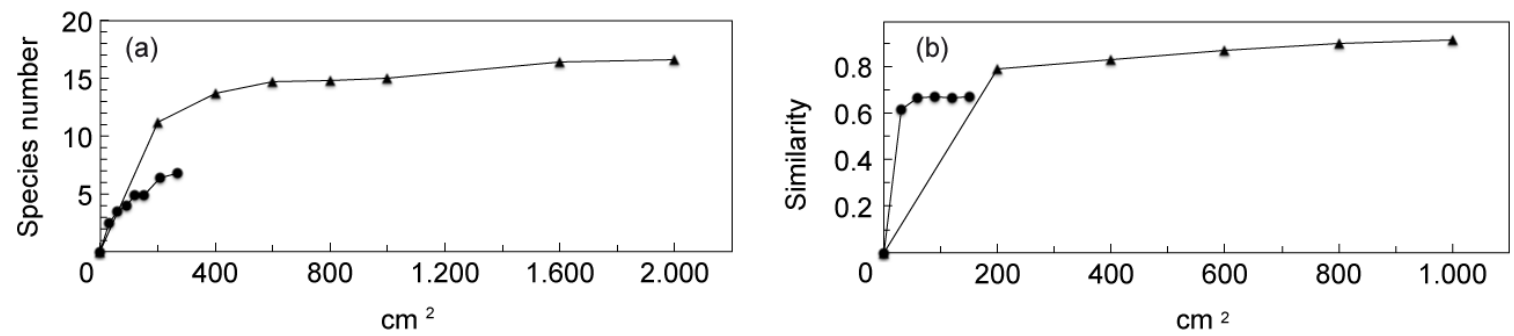

Figure 3.- (a) Curves of variance/mean ratio vs. area. (b) Diversity/area curves. (c) Kulczynski index/area curves. - - - Silty; - $\mathbf{-}-$, Sandy.
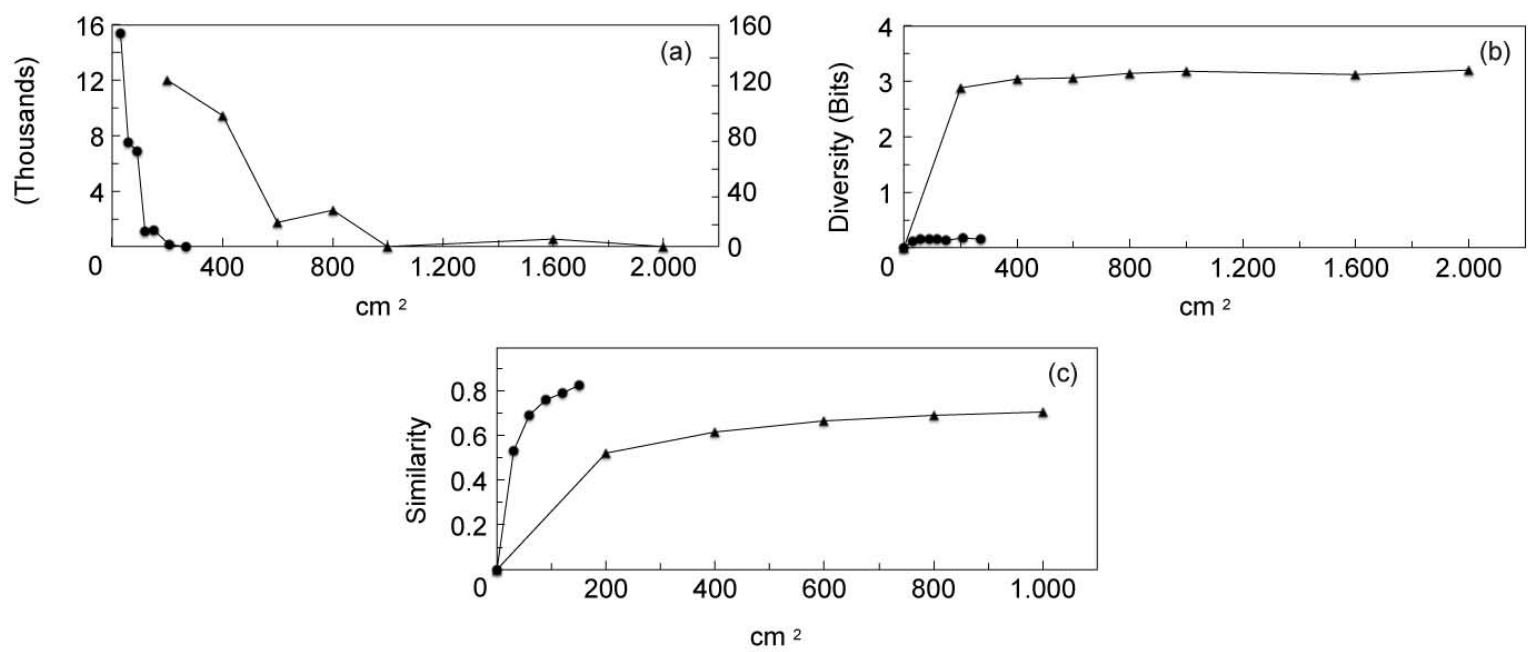
TABLE 1. Environmental factors in mud and sand comminities. \%SC: Silt and clay contents. \%OM: Organic matter contents. REDOX: Surface Redox potential of the sediments. DEPTH: Depth range of the wáter column on the sediment.

\begin{tabular}{lcc}
\hline Factors & Mud & Sand \\
\hline$\%$ SC & 15.16 & 0.06 \\
$\% O M$ & 1.82 & 0.78 \\
REDOX $(\mathrm{mV})$ & -103.00 & -8.30 \\
DEPTH $(\mathrm{cm})$ & $20-25$ & $50-100$ \\
\hline
\end{tabular}




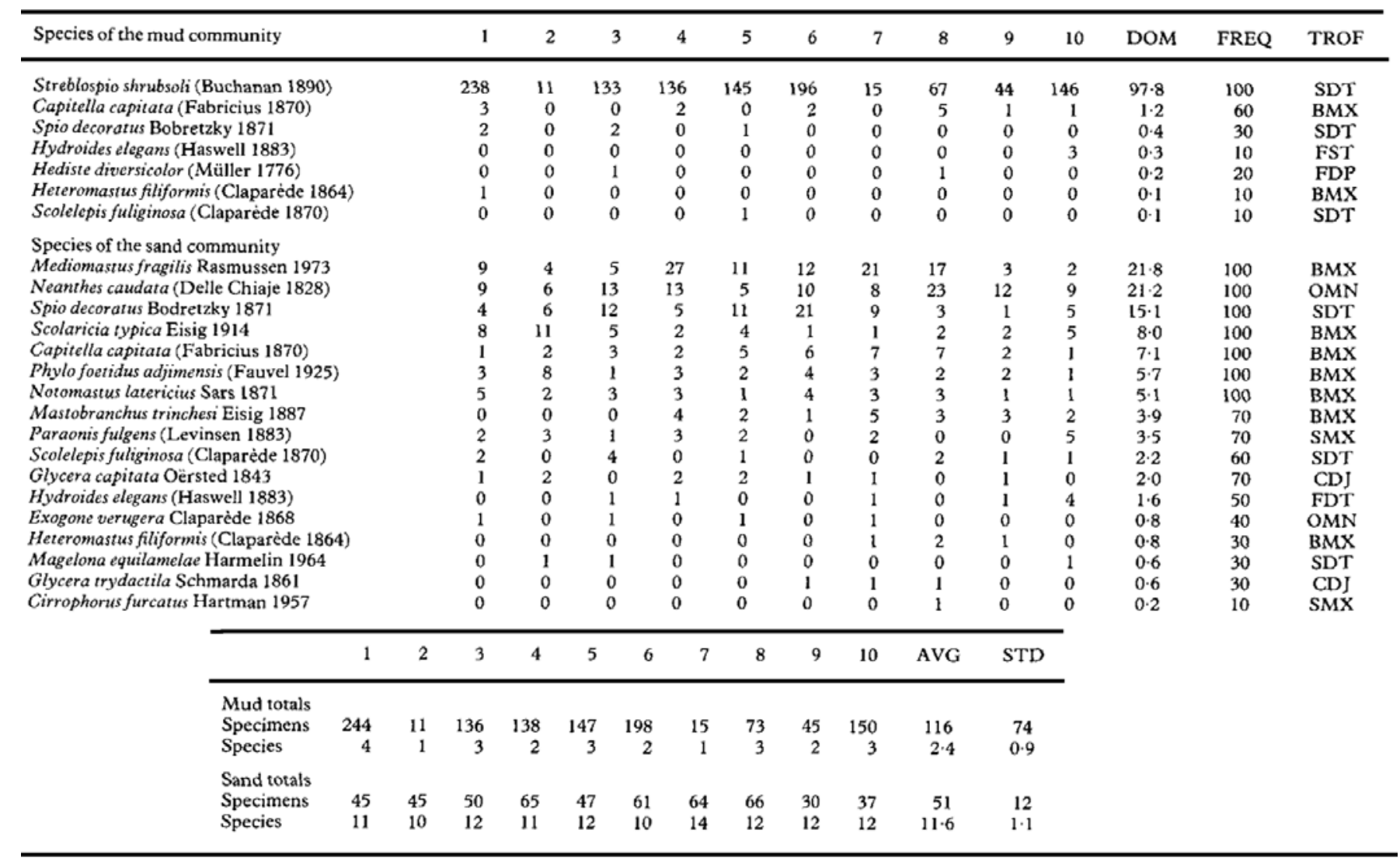

DOM: Dominance. FREQ: Frequency. TROF: Trophic category (sensu Fauchald \& Jumars, 1979, modified by Gambi \& Giangrande, 1985). SDT surface deposit-feeders, discretely motile, tentaculate. SMX: surface deposit-feeders, motile, sac-like pharynges. BMX: subsurface deposit-feeders, motile, sac-like pharynges. FST: filter-feeders, sessile, tentaculate. FDP: filter-feeders, discretely motile, pumping. OMN: Omnivores. CDJ: Carnivores, discretely motile, jawed. 